\title{
Bioremediation of diesel oil in marine environment
}

\author{
Riya Ann Mathew ${ }^{1, *}$ and Marykutty Abraham² \\ ${ }^{1}$ Department of Civil and Environmental Engineering, University of Houston, Houston, Texas 77204, United States \\ ${ }^{2}$ Centre for Remote Sensing and Geoinformatics, Sathyabama Institute of Science and Technology, Chennai 600119, India
}

Received: 10 November 2019 / Accepted: 6 July 2020

\begin{abstract}
Natural gas emissions from oil spill ensue changes to microbial consortia in oceans which might cause ecotoxicological impacts on marine life. Gas flaring, a technique in the clean-up of oil spill, is a major source of greenhouse gas emission and possess high risk of fire hazard. It is of utmost importance to avoid flaring and resort to cleaner techniques such as bioremediation. The study focuses on bioremediation of marine oil spill by indigenous bacterial consortia using beeswax as a biostimulant which supplements the limiting nutrients such as nitrate and phosphate. The experimental study was conducted by adding diesel oil in marine water with beeswax for bioremediation. The vital parameters such as dissolved oxygen, $\mathrm{pH}$, diesel range organics, total microbial count, nitrate and phosphate contents were measured at intervals of 5 days. The indigenous bacteria utilized oil as carbon source and beeswax as nutrient source for growth and metabolism. The results showed $87 \%$ removal of oil content in treatment sample while only $59 \%$ reduction was achieved in the corresponding control sample. Evaporation of oil results in formation of aerosols and black carbon which can lead to climate change. The study proves that bioremediation of marine oil spill is an environmentally benign clean-up technique for oil spill which can reduce carbon emission.
\end{abstract}

\section{Introduction}

Black carbon produced by flaring of oil spill has strong implications for climate change. It is short-lived with strong warming potential that can cause climate change. It absorbs sunlight more than it reflects which results in faster melting of ice caps. It also accounts for a quarter of observed warming and remediating the oil spill quickly is a means of mitigating the effects of climate change. Oil can be introduced into the ocean by natural, accidental and/or intentional spills.

Bioremediation employs microbial metabolism in the optimal environment with adequate nutrients to breakdown contaminants. Bioremediation is the process that utilizes bacteria, fungi and/or green plants to naturally remove contaminants. The two approaches to bioremediation are biostimulation and bioaugmentation. Zobell (1973) states that bioaugmentation is the introduction of bacteria to a spill site to supplement the indigenous microbial population in digesting the spilled petrochemicals. The other approach is biostimulation which is the introduction of nutrients and/or other growth enhancing substances to a spill site for the growth of indigenous microbes in order to accelerate the digestion of the spilled petrochemicals. The important factors influencing the efficiency of

\footnotetext{
* Corresponding author: riya.am@gmail.com
}

bioremediation are the type of microorganisms present in marine water, characteristics of the oil such as chemical composition, sorption, bio-availability, concentration and environment surrounding the spill such as moisture content, $\mathrm{pH}$, temperature and nutrients.

According to the Office of Technology Assessment (OTA), mechanical methods typically recover not more than $10-15 \%$ of the oil after a major oil spill (OTA, 1990). Unless the oil spill is contained in a boom it can drift very fast. Bioremediation is a promising technology for oil spill clean-up (OTA, 1991). Many of the components of oil are readily biodegradable in nature (Atlas, 1981, 1984; Prince 1993). Bioremediation is a safe cleanup method for marine oil spills (Prince and Atlas, 2016).

Studies on the British Petroleum oil spill reported injection of approximately 500000 tons of gaseous hydrocarbons into the ocean and the gaseous emissions constituted $40 \%$ of the total hydrocarbon discharge causing tremendous atmospheric pollution (Joye et al., 2011). Many researchers have studied various aspects of the tragic oil spill of Exxon Valdez in 1989, the use of bioremediation (Atlas \& Bragg 2009; Bragg et al. 1994; McDonnel 1992; Peterson et al. 2003; Pritchard et al. 1992) and the influence of temperature on biostimulation of marine oil spill (Coulon et al., 2007).

In-situ bioremediation was found to control many undesirable impacts of amendments on environment by conventional treatment methods (Brown et al, 1998; Franzetti et al, 2006; Joseph, 1998; Menendez-Vega et al., 2007; 
Volkering et al., 1997). Presence and activity of hydrocarbon degrading microorganisms were reported along the affected shorelines (Medina-Bellver et al, 2005). Researchers used fertilizers for bioremediation of marine oil spill and found it to be effective as the fertilizers rich in nitrate and phosphate provided nutrients for the oil degrading microorganisms (Gallego et al., 2008; Xu et al, 2005). Dominant genera observed in the marine water are Pseudomonas spp. and Bacillus spp. (Chikere et al., 2016). Catechol 2, 3 dioxygenases, a group of enzymes play important role in natural attenuation processes of hydrocarbon contaminated environment (Sierra-García et al., 2014). Comprehensive treatment of petroleum hydrocarbon by eventual manipulation of factors affecting bioremediation is technically and economically feasible (Adams et al., 2015).

Beeswax, a natural wax produced by honeybees, is used as a biostimulant for bioremediation of hydrocarbon in the present study. One $\mathrm{kg}$ of beeswax can store $22 \mathrm{~kg}$ honey (Coggshall and Morse, 1984). India accounts for the largest beeswax production of 22000 tons, which is $33 \%$ of the global production (Sergeeva, 2017). Beeswax can absorb oil up to 20 times its weight. It contains nitrogen, phosphorus and potassium which are used as nutrient source for the bacteria. It consists of $15 \%$ hydrocarbon, $8 \%$ free acids remaining esters. The melting point ranges from $62{ }^{\circ} \mathrm{C}$ to $64^{\circ} \mathrm{C}$ and density at $15^{\circ} \mathrm{C}$ ranges from 958 to $970 \mathrm{~kg} / \mathrm{m}^{3}$. Bioaugmentation could employ organisms that degrade hydrocarbons to be encapsulated in wax to form organism-containing wax microshells which are used for removing oil spills (JUSTIA, 2018). Bioremediation can be an effective, environmentally benign means of remediating oil spill in the marine water (Mathew et al., 2019).

\section{Study area and sample collection}

The marine sample was collected offshore of Besant Nagar beach, Chennai, India. Composite grab sampling was used to collect $10 \mathrm{~L}$ of sample in a clean plastic container. The site of sample collection was devoid of any immediate effluent plume from local discharge. The sample was collected during summer when the Dissolved Oxygen (DO) is lowest in order to prove the suitability of beeswax in bioremediation of marine oil spill even in the worst scenario. The DO and $\mathrm{pH}$ of the sample was analysed on the same day of collection. The sample was stored at $4{ }^{\circ} \mathrm{C}$ for later analysis.

\section{Methodology}

A lab-scale experiment to validate the effectiveness of beeswax as a biostimulant in the bioremediation of marine oil spill was carried out using diesel oil. During combustion, diesel oil produces approximately $13 \%$ more $\mathrm{CO}_{2}$ compared to petrol.

The collected marine water sample with diesel oil and beeswax as a nutrient source was taken as the treatment and the corresponding control consisted of marine water sample with diesel oil and without beeswax. The glass beakers with sample for the control and treatment were setup as shown in Figure 1. Six samples each was used for treatment and control. Three samples were used for the analysis of Diesel Range Organics (DRO) corresponding to $5^{\text {th }}, 10^{\text {th }}$ and $15^{\text {th }}$ day and the other three samples for parameters such as $\mathrm{pH}, \mathrm{DO}$, nitrate, phosphate and microbial count. The chemical formula for diesel oil ranges from $\mathrm{C}_{10} \mathrm{H}_{20}$ to $\mathrm{C}_{15} \mathrm{H}_{28}$, DRO is a good indicator of diesel content as it corresponds to the range of hydrocarbon from $\mathrm{C} 10$ to $\mathrm{C} 28$ (API, 1994).

Initial characterisation of the sample was carried out for vital parameters. $500 \mathrm{~mL}$ marine sample, $15 \mathrm{~mL}$ diesel oil and $5 \mathrm{~g}$ beeswax as pellets were added to the treatment beaker while no beeswax was added to the control. Vital parameters such as $\mathrm{DO}, \mathrm{pH}$, nitrate, phosphate, and total microbial count were analysed at intervals of 5 days for 15 days. All analyses were in accordance with the American Public Health Association (APHA, 2005) standard procedure. In addition, DRO was also analysed during the same interval. DRO was analysed using Gas ChromatographyMass Spectrometry (GC-MS). Another two samples were used for the analysis of oil content in the control and treatment at the end of the experiment to show the effective removal of diesel oil by evaporating the sample and measuring the remaining oil content using Soxhlet Extraction Method (Standard Methods American Water Works Association 5520 part D). Oil content was also analysed initially in the raw marine sample to determine the presence of any oil content. Average of three samples was obtained and represented graphically.

\section{Results and discussion}

The values of various parameters obtained in the experimental study is tabulated (Tab. 1). Significant reduction in DRO and oil content was observed in treatment compared to control after 15 days of experiment.

\section{$4.1 \mathrm{pH}$}

The $\mathrm{pH}$ of the samples varied between 6.64 and 7.72 in both treatment and control (Fig. 2). The optimal $\mathrm{pH}$ for the growth of microorganism to degrade hydrocarbon ranges from 6 to 8 (Leahy \& Colwell, 1990). The $\mathrm{pH}$ was within optimal range for the degradation of oil by microbes.

\subsection{Dissolved oxygen}

The initial DO of marine water sample was $6.5 \mathrm{mg} / \mathrm{L}$ which correlates with the DO of marine water at $35^{\circ} \mathrm{C}$. The oil degrading bacteria that utilise oil as their carbon source are mostly aerobic and require DO for cellular respiration. The DO continues to reduce as no aeration is given to both the treatment and control. The DO in treatment reduces steadily which corresponds to oxygen consumption by aerobic oleophilic bacteria signifying the degradation of oil. (Fig. 3). At the end of 15-day experiment, the DO reduced to $4.9 \mathrm{mg} / \mathrm{L}$ which is adequate for the growth of microbes. In control the DO is lower than treatment initially which indicates the high oil content that does not 

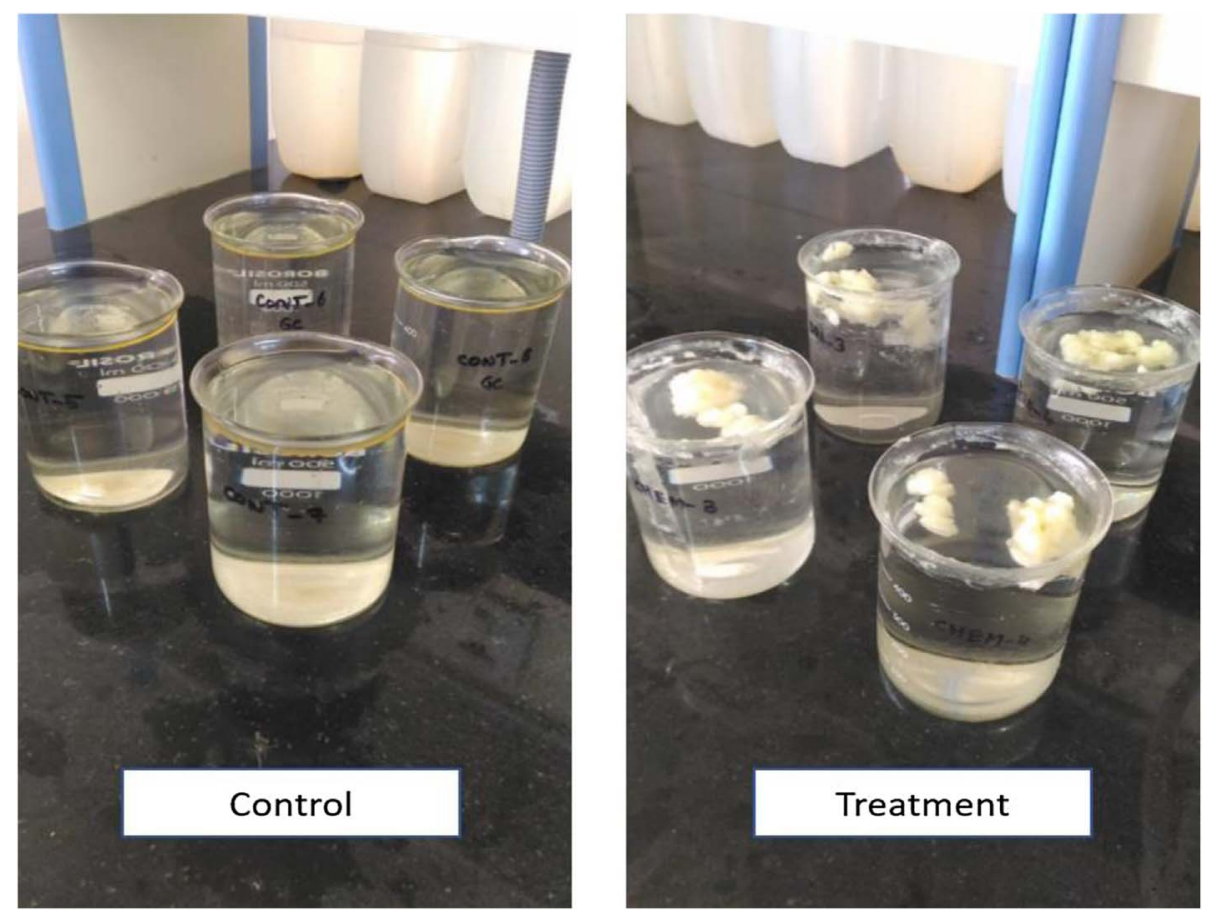

Fig. 1. Experimental Setup.

Table 1. Values of various parameters obtained in the experiment.

\begin{tabular}{|c|c|c|c|c|c|c|c|c|}
\hline Parameter & Unit & $\begin{array}{c}\text { Raw } \\
\text { sample }\end{array}$ & \multicolumn{2}{|c|}{$5^{\text {th }}$ day } & \multicolumn{2}{|c|}{$10^{\text {th }}$ day } & \multicolumn{2}{|c|}{$15^{\text {th }}$ day } \\
\hline $\mathrm{DO}$ & $\mathrm{mg} / \mathrm{L}$ & 6.5 & 5.8 & 6.3 & 5.7 & 5.8 & 5.1 & 4.9 \\
\hline $\mathrm{NO}_{3}$ & $\mathrm{mg} / \mathrm{L}$ & 1.285 & 1.16 & 1.21 & 1.085 & BQL (LOQ:1) & BQL (LOQ:1) & BQL (LOQ:1) \\
\hline $\begin{array}{l}\text { Microbial } \\
\text { count }\end{array}$ & $\mathrm{CFU} / \mathrm{mL}$ & 410 & 120 & 2200 & 90 & 1900 & 70 & 1800 \\
\hline DRO & ppm & & 1361 & 1252 & 877 & 538 & 365 & 98 \\
\hline Oil content & $\mathrm{mL}$ & 15 & & & & & 6.2 & 2 \\
\hline
\end{tabular}

BQL: Below quantifiable limit; LOQ: Limit of Quantification.

actively degrade as in treatment, thus limits the oxygen transfer from the atmosphere to the water.

\subsection{Nutrients - Nitrate and Phosphate}

The beeswax added after initial characterization of the marine water sample is the source of nitrate and phosphate which are essential nutrients for the growth of indigenous microbes. The sample had an initial nitrate content of $1.285 \mathrm{mg} / \mathrm{L}$ (Fig. 4). After the addition of beeswax, the nitrate reduced significantly in the treatment within 5 days and the nitrate concentrations for $10^{\text {th }}$ and $15^{\text {th }}$ day were below detection limit (limit of detection: $1 \mathrm{mg} / \mathrm{L}$ ). This is due to the rapid consumption of nitrate by the proliferating indigenous microbes and the growth rate increased by 5 folds in 5 days. Later the microbial count reduced due to the deficit of nitrate. The initial concentration of phosphate in the marine water sample was $1.5 \mathrm{mg} / \mathrm{L}$. The addition of beeswax increased the phosphate content in the treatment initially which depleted slowly as only 1 part of phosphate is consumed for every 10 parts of nitrate. It reduced after $10^{\text {th }}$ day as there was no further addition of beeswax (Fig. 5). In the control, phosphate steadily reduced and was below detection limit on the $15^{\text {th }}$ day (Limit of detection: $0.2 \mathrm{mg} / \mathrm{L}$ ). The ratio of nitrate to phosphate required for the optimal growth of bacteria is 10:1. 


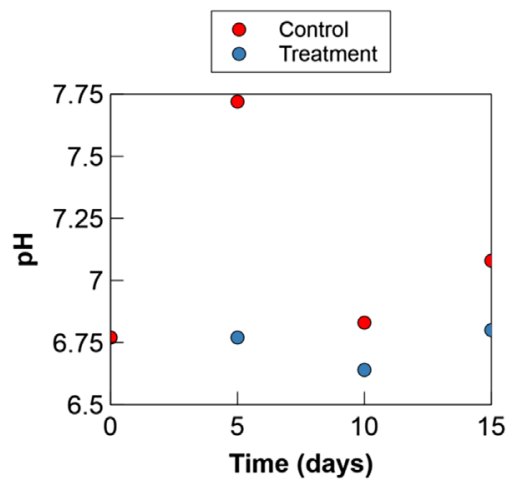

Fig. 2. Temporal variation of $\mathrm{pH}$.

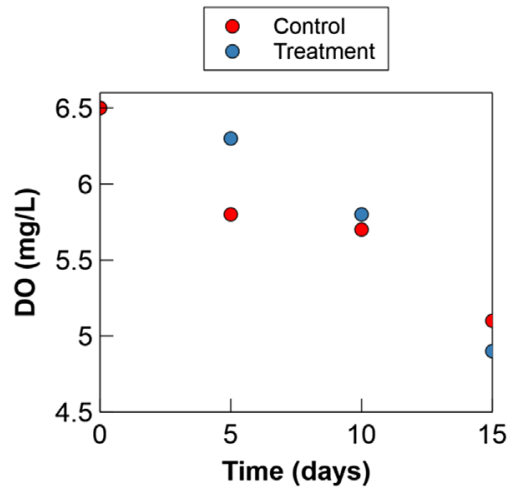

Fig. 3. Temporal variation of DO content.

\subsection{Total Microbial Count}

The dominant species of bacteria present in marine sample are Bacillus spp. and Pseudomonas spp. Microbial count measured as Colony Forming Units (CFU) increased from 410 to $2200 \mathrm{CFU} / \mathrm{mL}$ (Fig. 6) in the treatment which is a five-fold increase during the initial 5 days due to the abundance of nutrients from beeswax and the presence of DO in the sample but after $5^{\text {th }}$ day, the microbial population reduced slowly in the treatment. On the other hand, it reduced very rapidly in the control and was $70 \mathrm{CFU} / \mathrm{mL}$ on $15^{\text {th }}$ day as the nutrient source and dissolved oxygen was limiting. The nitrate and phosphate are consumed by the bacteria for their growth and metabolism. The aerobic bacteria consume DO for their cellular respiration and oil as their carbon source. The significant difference in the microbial count in treatment and control indicates the importance of nutrients for the growth of microbes which could be supplemented by addition of biostimulant such as beeswax. Hence optimal nutrient level by insitu biostimulation aids in the bioremediation of marine oil spill.

\subsection{Diesel Range Organics}

Diesel Range Organics (DRO) is used as a specific indicator of diesel oil in marine water. It was found to reduce significantly in the treatment to 98 ppm after 15 days whereas in

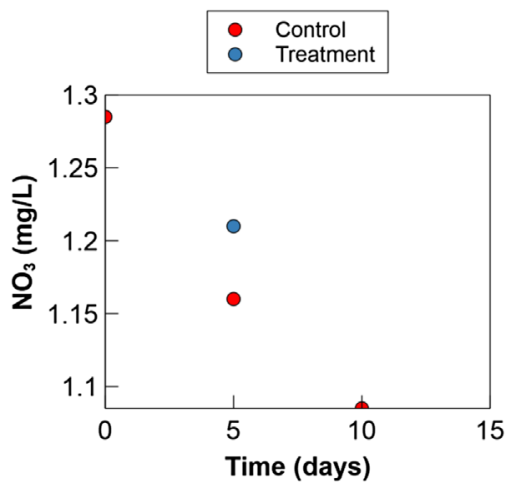

Fig. 4. Temporal variation of nitrate concentration.

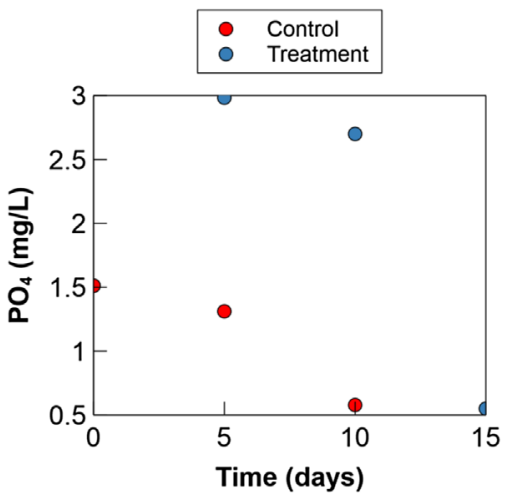

Fig. 5. Temporal variation of phosphate concentration.

the control it reduced only to 365 ppm (Fig. 7). The reduction was more prominent in treatment due to the profuse growth of oleophilic microbes resulting from the addition of biostimulant namely beeswax leading to the bioremediation of diesel oil.

\subsection{Oil content}

The oil content in the initial marine water sample, measured using soxhlet extraction method, was below detection limit. $15 \mathrm{~mL}$ of diesel oil was added to marine water in treatment and control. The oil content reduced to $2 \mathrm{~mL}$ and $6.2 \mathrm{~mL}$ in the treatment and control respectively after 15 days of treatment (Fig. 8). The reduction in oil content was measured by evaporating the sample in a rotary evaporator. The treatment has a removal efficiency of $87 \%$ while in control only $59 \%$ oil removal was achieved. In control, the hydrocarbons in oil can undergo phase transformation by evaporation, dissolution and dispersion. It results in the formation of aerosols which could lead to smog and their presence in the atmosphere may cause global warming thus effect the air quality. Studies by Butler et al. (1976) showed that $25 \%$ of the crude oil was evaporated naturally within 10 days. The components of oil could accumulate in food chain thus adversely affecting the aquatic environment and human health. Hence it is important to remediate marine oil spill. 


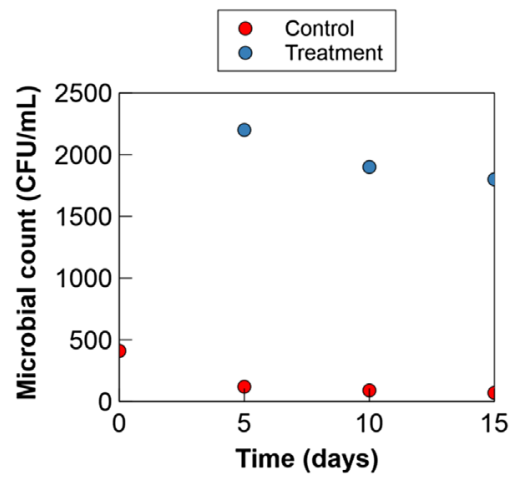

Fig. 6. Temporal variation of microbial count.

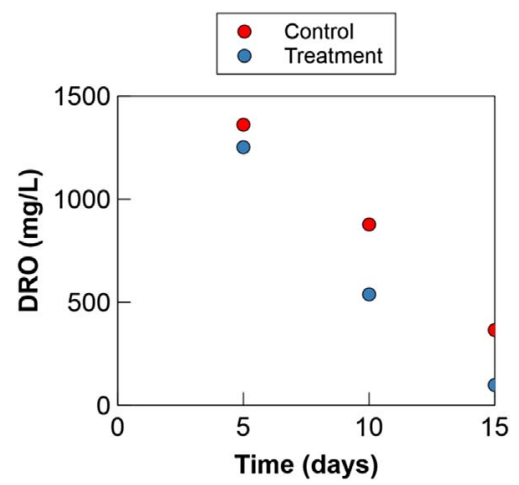

Fig. 7. Temporal variation of Diesel Range Organics.

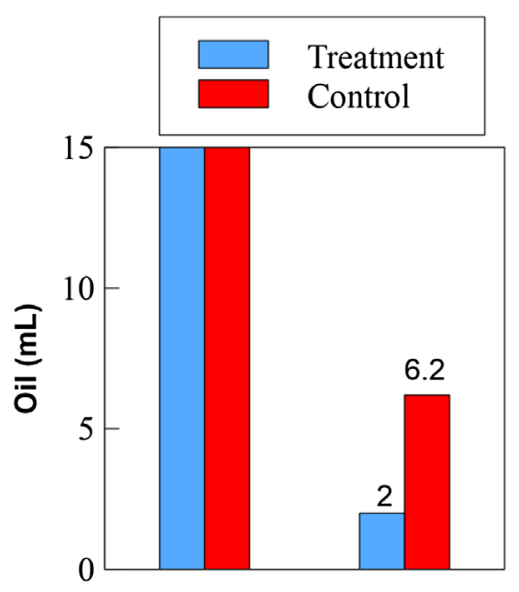

Fig. 8. Reduction in Oil Content during the experiment.

\section{Conclusion}

Bioremediation is an effective technique in the clean-up of petrochemical spills because it is a process of naturally converting petrochemicals into non-toxic by-products without any further local environmental disruption using microorganisms. Beeswax, a biostimulant, provides bacteria the nutrients required for its growth and metabolism. The microbes use hydrocarbon in oil as the carbon source while dissolved oxygen is used for the cellular respiration. Nitrate and phosphate are limiting in marine environment which needs to be supplemented for the rapid growth of microbes. In the present study, the addition of beeswax resulted in five-fold increase in the microbial count by the consumption of nutrients in beeswax. The experimental study conducted on the bioremediation of marine oil spill using beeswax achieved $87 \%$ removal of oil in 15 days while only $59 \%$ was removed in control. The diesel range organics reduced more in treatment than control. The removal of oil in the control is mainly due to evaporation, dissolution and sedimentation which can cause atmospheric pollution, global warming and climate change, whereas in treatment the hydrocarbon is consumed by oleophilic microbes without producing any harmful by-products. Hence bioremediation is advantageous over conventional methods, in terms of pollution abatement, cost effectiveness, insitu and environmentally benign treatment.

\section{References}

Adams G.O., Fufeyin P.T., Okoro S.E., Ehinomen I. (2015) Bioremediation, Biostimulation and Bioaugmention: A Review, Int. J. Environ. Bioremediat. Biodegrad. 3, 1, 28-39.

APHA. (2005) Standard Methods for Examination of Water and Wastewater, 21st ed., American Public Health Association/ American Water Works Association/Water Environment Federation, Washington DC, USA.

API (American Petroleum Institute) Health and Environmental Sciences Department. (1994) Interlaboratory study of three methods for analyzing petroleum hydrocarbons in soils: dieselrange organics (DRO), gasoline-range organics (GRO), petroleum hydrocarbons (PHC), American Petroleum Institute Publications - Series: 4599, Washington, DC, USA.

Atlas R.M. (1981) Microbial degradation of petroleum hydrocarbons: An environmental perspective, Microbiol. Rev. 45, 1, 180-209.

Atlas R.M. (ed.) (1984) Petroleum Microbiology, Macmillan Publishing Company, New York.

Atlas R., Bragg J.R. (2009) Bioremediation of marine oil spills: when and when not - the Exxon Valdez experience, Microbial Biotechnol. 2, 213-221.

Bragg J.R., Prince R.C., Harner E.J., Atlas R.M. (1994) Effectiveness of bioremediation for the Exxon Valdez oil spill, Nature 368, 413-418.

Brown J.L., Syslo J.L., Yi-Hua L.L., Getty S.L., Ve-Muri R.L., Nadeau R.L. (1998) On-site treatment of contaminated soils: An approach to bioremediation of weathered petroleum compounds, J. Soil Contam. 7, 6, 773-800.

Butler J.N., Morris B.F., Sleeter T.D. (1976) The Fate of Petroleum in the Open Ocean, in: Proceedings of the Symposium: Sources, Effects and Sinks of Hydrocarbons in the Aquatic Environment. Washington D.C August 9-11, The American Institute of Biological Sciences, Arlington VA, pp. 287-297.

Chikere C.B., Okoye A.U., Okpokwasili G.C. (2016) Bacterial community dynamics of nutrient enhanced oil-polluted sediment, Nigerian J. Microbiol. 30, 1, 3281-3294.

Coggshall W.L., Morse R.A. (1984) Beeswax production, harvesting, processing and products, Wicwas Press, Ithaca, New York. 
Coulon F., McKew B.A., Osborn A.M., McGenity T.J., Timmis K.N. (2007) Effects of temperature and biostimulation on oildegrading microbial communities in temperate estuarine waters, Environ. Microbiol. 9, 1, 177-186.

Franzetti A., Gennaro P.D., Bevilacqua A., Papacchini M., Bestetti G. (2006) Environmental features of two commercial surfactants widely used in soil remediation, Chemosphere $\mathbf{6 2}$, 9, 1474-1480.

Gallego J.R., Menéndez-Vega D., González-Rojas E., Sánchez J., García-Martínez M.J., Llamas J.F. (2008) Oleophilic fertilizers and bioremediation: A new perspective, in: Modern multidisciplinary applied microbiology: Exploiting microbes and their interactions, Wiley-VCH, Badajoz, Spain, pp. 551-555.

JUSTIA patents. (2018) https://patents.justia.com/patent/ 5807724 (accessed on 15th June 2018).

Joseph A.R. (1998) Degradation of petroleum hydrocarbons with organisms encapsulated in wax, USPTO. https://patentimages.storage.googleapis.com/ff/71/50/33e04b54a07a68/

US5807724.pdf (accessed on 15th June 2018).

Joye S.B., MacDonald I.R., Leifer I., Asper V. (2011) Magnitude and oxidation potential of hydrocarbon gases released from the BP oil well blowout, Nat. Geosci. 4, 3, 1-5.

Leahy J.G., Colwell R.R. (1990) Microbial degradation of hydrocarbons in the environment, Microbiol. Rev. 54, 3, 305-315.

Mathew R.M., Lavanya V., Rasiga S., Abraham M. (2019) Bioremediation of marine oil spill using beeswax, Indian J. Geo-Marine Sci. 48, 8, 1227-1231.

McDonnel J.A. (1992) The U.S. Army Corps of Engineers Response to the Exxon Valdez Oil Spill, U.S. Army Corps of Engineers, Fort Belvoir, Virginia.

Medina-Bellver J.I., Marín P., Delgado A., Rodríguez-Sánchez A., Reyes E., Ramos J.L., Marques S. (2005) Evidence for in situ crude oil biodegradation after the Prestige oil spill, Environ. Microbiol. 76, 773-779.

Menendez-Vega D., Gallego J.L.R., Pelaez A.I., Fernandez De Cordoba G., Moreno J.H., Muñoz D., Sánchez J. (2007) Engineered in situ bioremediation of soil and groundwater polluted with weathered hydrocarbons, Eur. J. Soil Biol. 43, $5,310-321$.
OTA (Office of Technology Assessment) U.S. Congress. (1990) Coping with an Oiled Sea: An Analysis of Oil Spill Response Technologies. OTA-BP-O-63, U.S. Government Printing Office, Washington, DC

OTA (Office of Technology Assessment) U.S. Congress. (1991) Bioremediation of Marine Oil Spills: An Analysis of Oil Spill Response Technologies. OTA-BP-O-70, U.S. Government Printing Office, Washington, DC.

Peterson C.H., Rice S.D., Short J.W., Esler D., Bodkin J.L., Ballachey B.E., Irons D.B. (2003) Long-term ecosystem response to the Exxon Valdez oil spill, Science 302, 5653, 2082-2086.

Prince R.C. (1993) Petroleum spill bioremediation in marine environments, Crit. Rev. Microbiol. 19, 4, 217-242.

Prince R.C., Atlas R.M. (2016) Bioremediation of Marine Oil Spills, in: Consequences of microbial interactions with hydrocarbons, oils, and lipids: biodegradation and bioremediation. Handbook of Hydrocarbon and Lipid Microbiology, Steffan R. (ed.), Springer, Cham.

Pritchard P.H., Mueller J.G., Rogers J.C., Kremer F.V., Glaser J.A. (1992) Oil spill bioremediation: experiences, lessons and results from the Exxon Valdez Oil Spill in Alaska, Biodegradation 3, 2-3, 315-335.

Sergeeva A. (2017) Index box: Which country produces the most beeswax in the World?

Sierra-García I.N., Correa Alvarez J., Pantaroto de Vasconcellos S., Pereira de Souza A., dos Santos Neto E.V., de Oliveira V.M. (2014) New Hydrocarbon Degradation Pathways in the Microbial Metagenome from Brazilian Petroleum Reservoirs, PLoS ONE 9, 2, e90087.

Volkering F., Breure A.M., Rulkers W.H. (1997) Microbiological aspects of surfactant use for biological soil remediation, Biodegradation 8, 6, 401-417.

Xu R., Lau A.N., Lim Y.G., Obbard J.P. (2005) Bioremediation of oil-contaminated sediments on an inter-tidal shoreline using a slow-release fertilizer and chitosan, Mar. Pollut. Bull. 51, 8-12, 1062-1070.

Zobell C.E. (1973) Microbial degradation of oil: present status, problems and perspectives, in: The microbial degradation of oil pollutants, Ahearn D.G., Meyers S.P. (eds.), Pub. No. LSUSG-73-0, Center for Wetlands resources, LSU, pp. 3-15. 